WACŁAW URUSZCZAK

iD http:/orcid.org/0000-0002-3937-1672

Państwowa Wyższa Szkoła Zawodowa w Tarnowie

\title{
Laudacja na uroczystość 90. rocznicy urodzin Profesora Stanisława Grodziskiego. Konferencja naukowa "Eq̨zza nas źródła" (Kraków, 19 września 2019 r.)
}

\section{Laudation at the Celebration of the 90th Anniversary of the Birth of Professor Stanisław Grodziski. Scientific Conference "Sources connect us" (Kraków, 19th September 2019)}

Magnificencjo, Pani Rektor, Panie Dziekanie, Panie i Panowie Profesorowie, Szanowni Zebrani, ale nade wszystko Dostojny Panie Profesorze, dzisiejszy Jubilacie! Drogi Kolego i Przyjacielu, Drogi Stanisławie!

Dzisiejsze naukowe spotkanie poświęcone jest prezentacji osiągnięć i wymianie opinii na temat edycji źródeł historycznoprawnych. Jest więc najzupełniej na miejscu, aby na spotkanie to został zaproszony i szczególnie uhonorowany ten, kto na polu edycji źródłowych ma największe osiągnięcia, i ten, kto wniósł szczególny wkład w tego rodzaju dzieło.

Prof. Stanisław Grodziski skończył w tym roku 90 lat. Jego dorosłe, w szczególności zawodowe, życie przypadło w większości na czasy Polski pod rządami komunistów. Należy tutaj przypomnieć, że Profesor nie należał nigdy do zwolenników komunistycznej władzy. Jego biografia nie notuje więc takich momentów przełomowych, kiedy ktoś z komunisty przepoczwarzył się w liberała, czy z marksisty na rzecznika strukturalizmu czy czegoś podobnego. Nie musiał też oddawać legitymacji partyjnej, bo jej nigdy nie posiadał. Zawsze pozostawał sobą, człowiekiem pracy pozytywnej przywiązanym do tradycyjnych wartości, takich jak miłość ojczyzny (chodzi oczywiście o Polskę), tradycyjna rodzina czy szacunek dla Kościoła, czy wreszcie po prostu prawda. Był też bez cienia wątpliwości człowiekiem uniwersytetu, dostrzegającym wielkie znaczenie tej instytucji dla polskiego społeczeństwa. Jestem młodszym kolegą Profesora, który miał zaszczyt pracować pod Jego kierownictwem i być Jego współpracownikiem. Oboje uważaliśmy, że naszym zadaniem jest jak najlepsze wykonywanie naszych obowiązków, 
a więc praca pozytywna zgodnie ze znanym apelem Wojciecha Młynarskiego „Róbmy swoje".

90 lat życia to imponujący jubileusz, który w szczególności skłania do wyrażenia Profesorowi naszej wdzięczności za wielkie dzieło Jego życia.

Stanisław Grodziski ma za sobą piękną karierę uniwersytecką. W Alma Mater Jagiellonica pełnił on różnorodne odpowiedzialne funkcje, jak kierownik Zakładu Historii Państwa i Prawa Polskiego, kierownik Katedry Powszechnej Historii Państwa i Prawa, kierownik, a zarazem założyciel Pracowni Wydawnictw Źródłowych, Dziekan Wydziału Prawa i Administracji, prorektor do spraw studenckich. Tę ostatnią funkcję sprawował w latach 1987-1990 w czasach transformacji ustrojowej i walki o reformę kraju i szkolnictwa wyższego.

Ukończywszy studia w 1951 roku, ówczesny absolwent Wydziału Prawa, młody, bo zaledwie 22-letni, Stanisław Grodziski związał swoje dalsze losy ze środowiskiem historycznoprawnym Uniwersytetu Jagiellońskiego. W szczególności jego naukowym mistrzem był prof. Adam Vetulani, jeden z najwybitniejszych profesorów Wydziału w tamtym okresie, znakomity historyk prawa polskiego i kanonista o międzynarodowej sławie. To właśnie pod kierunkiem prof. Vetulaniego nasz dzisiejszy Jubilat zdobywał kolejne stopnie naukowe, a zarazem współpracował w dziedzinie edycji źródeł prawa. Warto przypomnieć, że wydawanie źródeł prawa to działalność prowadzona w Katedrze Historii Prawa Polskiego od początków jej istnienia. Pierwszym profesorem tej dyscypliny był Antoni Zygmunt Helcel (1808-1870), który zasłynął jako wydawca Statutów Kazimierza Wielkiego, zapisek sądów ziemskich i grodzkich krakowskich. Źródła te zostały opublikowane w tomach I i II założonej przez Helcla serii pt. „Starodawne Prawa Polskiego Pomniki”. Dzieło wydawnicze kontynuował Michał Bobrzyński (1849-1935), do dzisiaj uznawany za jednego z najwybitniejszych historyków polskich. W rzeczywistości był on historykiem prawa. Jego dziełem były dalsze tomy wspomnianej serii, gdzie ukazała się „Korektura praw” z 1532 r., a także pomniki staropolskiej literatury prawniczej. To właśnie Bobrzyński był odkrywcą Pawła Włodkowica, opublikował główne jego dzieła. Wydał także dekrety sądów królewskich i przywileje nieszawskie. Następcami Bobrzyńskiego byli Franciszek Piekosiński (1844-1906), Bolesław Ulanowski (1860-1919) i Stanisław Kutrzeba (1876-1946), wielce zasłużeni badacze historii prawa i wydawcy źródeł. W szczególności Piekosiński był wydawcą dokumentów średniowiecznych, Kutrzeba zaś wśród wielu różnorodnych źródeł wydał wraz z Władysławem Semkowiczem Akta Unii Polski z Litwa (1932) czy Akta sejmikowe województwa krakowskiego (1932), pomniki staropolskiego prawa wojskowego oraz zapiski sądu żydowskiego krakowskiego. Należy podkreślić z całą mocą, że właśnie wydawanie źródeł stanowi istotny impuls do podjęcia badań w danym zakresie, dzięki czemu edycje źródłowe przyczyniają się do postępu w nauce. Dobrze rozumiał to Adam Vetulani (1901-1976), który był mistrzem naszego Jubilata, a zarazem innych przyszłych profesorów, jak Ludwika Łysiaka (1923-2002), Stanisława Płazy (1927-2006), a także moim. Profesor Vetulani był prawdziwą osobowością naukową, obdarzony umiejętnością przyciągania do siebie młodych adeptów naukowego kunsztu, pragnących pod kierunkiem mistrza uczyć się naukowego rzemiosła. Wydawanie źródeł, w szczególności wspólna praca nad przygotowywaniem takich edycji, było okazją do wzajemnego dialogu i obfitego czerpania nauk z wiedzy udostępnianej przez mistrza. 
Profesor Grodziski, zanim stał się mistrzem w dziedzinie edytorstwa, współpracował z prof. Vetulanim przy wydawaniu ksiąg sądowych wiejskich, a następnie sam podjął tego rodzaju dzieło wydawnicze, publikując księgę klucza jazowskiego i księgę sądową hrabstwa tarnowskiego. W latach pracy nad księgami sądowymi wiejskimi (były to lata pięćdziesiąte i sześćdziesiąte ubiegłego wieku) między Stanisławem Grodziskim a Ludwikiem Łysiakiem wywiązała się żywa polemika w sprawie genezy tych ksiąg. Według prof. Grodziskiego księgi sądowe wiejskie pojawiły się w Małopolsce za wzorem sądów miejskich i szlacheckich, ze względu na bardziej zaawansowany rozwój stosunków społeczno-gospodarczych, umiarkowane oblicze poddaństwa feudalnego i rozwinięty samorząd gromadzki. Według Ludwika Łysiaka księgi takie w zasadzie pojawiły się na całym obszarze Królestwa Polskiego i Rzeczypospolitej, a fenomen zachowania ich w większej liczbie w Polsce Południowej to rezultat akcji Grona Konserwatorów Galicji Zachodniej w drugiej połowie XIX w. Do dzisiaj te dwa poglądy są obecne w literaturze naukowej.

Dodajmy na koniec także to, że liczba wydanych drukiem ksiąg sądowych wiejskich to zaledwie skromny ułamek ksiąg tego rodzaju, które w formie gotowych odpisów są przechowywane jako tzw. Teki Adama Vetulaniego w Katedrze Historii Prawa Polskiego, a ściślej w Pracowni Wydawnictw Źródłowych, placówki powstałej z inicjatywy Profesora Grodziskiego w 1978 r., w której do chwili obecnej prowadzone są prace edytorskie.

Wybitnym dziełem przygotowanym do wydania przez prof. Grodziskiego był Dziejopis Żywiecki Andrzeja Komonieckiego. Jest to kronika napisana w XVII w. przez wójta miasta Żywca, wspomnianego Komonieckiego. W części zostało ono wydane w 1937 r. przez Stanisława Szczotkę. W 1987 r. zostało opublikowane ponownie, ale już w całości, przez Stanisława Grodziskiego i Irenę Dwornicką, przedwcześnie zmarłą w 2002 r. asystentkę zatrudnioną w Pracowni Wydawnictw Źródłowych. Miałem zaszczyt współpracować z panią Ireną nad edycją Volumina Constitutionum. Chodzi tutaj o nowe wielkie przedsięwzięcie wydawnicze, zainicjowane i kontynuowane do dzisiaj z udziałem prof. Grodziskiego.

Czym są Volumina Constitutionum? Jest to w istocie seria tomów publikujących ustawy sejmów walnych koronnych w połączeniu z opisem poszczególnych kolejnych tego rodzaju zgromadzeń. Henryk Olszewski określił tę serię mianem „wielkiej inicjatywy naukowej i organizacyjnej". Wydawnictwo powstało w odpowiedzi na postulowaną przez środowisko historyków prawa polskiego reedycję Volumina Legum. Chodziło o wydawnictwo ustaw sejmowych, podjęte w XVIII w. przez Stanisława Konarskiego i Józefa Andrzeja Załuskiego jako zbiór obowiązującego w tamtych czasach prawa polskiego. Jednakże w XX w. prosta reedycja Volumina Legum mijała się z celem. Wydawnictwo to nie było kompletne i nie spełniało wymagań naukowych jako źródło historycznoprawne. Przedsięwzięcie było trudne. Należało bowiem wydanie to poprzedzić kwerendą pozwalającą na zgromadzenie wszystkich aktów prawnych będących bezpośrednio lub pośrednio owocem sejmów staropolskich. To zamierzenie w ogólności się powiodło, choć nie jest jeszcze zakończone. Z udziałem prof. Grodziskiego, śp. Ireny Dwornickiej i moim powstały pierwsze edycje, w szczególności t. I i II. Z kolei do współpracy przystąpili inni koledzy, jak 
prof. Marcin Kwiecień, dr Anna Karabowicz, dr Krzysztof Fokt. Do chwili obecnej wydano osiem tego rodzaju tomów.

W ubiegłym roku obchodzona była rocznica 550-lecia polskiego parlamentaryzmu. Volumina Constitutionum ukazują, jak poważny był dorobek ustawodawczy sejmów staropolskich. Wydawnictwo to ad oculos zaprzecza wszystkim sceptykom, którzy odmawiali staropolskiemu sejmowi, czy - szerzej - systemowi parlamentarnemu Pierwszej Rzeczypospolitej zdolności do pozytywnego wypełniania zadań na polu prawodawstwa w obliczu poważnych zagrożeń bezpieczeństwa zewnętrznego i wewnętrznego państwa. Dowiódł to zresztą zwłaszcza Sejm Czteroletni i jego ogromny dorobek ustawodawczy. Zainicjowanie edycji Volumina Constitutionum, kierowanie tym wydawnictwem, osobisty wkład w treść poszczególnych tomów po dzień dzisiejszy to wielka zasługa Profesora Stanisława Grodziskiego.

Poza wymienionymi prof. Grodziski wydawał także inne źródła, jak Charta Leopoldina, czyli projekt konstytucji dla Galicji z 1790 r. (wspólnie z Arturem Gerhardtem), dwa tomy „Akt Sejmu Krajowego Galicyjskiego” z lat 1861-1914 oraz wiele innych mniejszych edycji.

Laudacja nie jest kompletna. Ograniczyłem ją - zgodnie z prośbą organizatorów dzisiejszego spotkania - do wydawnictw źródłowych. Uważam, że dzieło to samo przez się dowodzi wielkości dokonań Jubilata, który dzięki tego rodzaju edycjom wzbogacił w sposób szczególny znajomość polskich tradycji ustrojowych i prawnych.

Na koniec pozwolę sobie zacytować moje słowa z laudacji wygłoszonej w 2011 r.:

Praca, a właściwie służba dla nauki, dla Uniwersytetu, zaskarbiła profesorowi Grodziskiemu uznanie i podziw całego środowiska, i to nie tylko historyków prawa, prawników czy historyków, ale całej społeczności uniwersyteckiej, a także wielu innych środowisk. Zyskał je dzięki ogromnej pracowitości, wielkiej kulturze osobistej, jak również wrodzonej życzliwości, którą okazywał zwłaszcza młodszym pracownikom i studentom. Dla wszystkich nas jest on autorytetem naukowym i moralnym. [...] za wszystkie Jego dzieła, za całość Jego dokonań i za wszystko, co sobą reprezentuje, pragnę wyrazić Profesorowi Grodziskiemu serdeczne podziękowanie, a zarazem życzyć Mu zdrowia i dalszych pięknych sukcesów.

Ad multos annos Dostojny Profesorze Stanisławie! 